\title{
Studies of reactivity of some Sri Lankan population groups to antigens of Mycobacterium leprae. III. The post-lepromin test scar in healthy populations in Sri Lanka
}

\author{
M R M PINTO,* N B ERIYAGAMA* \\ $\&$ V PEMAJAYANTHA $\dagger$ \\ * Department of Microbiology, Faculty of Medicine, University of \\ Peradeniya, Peradeniya; $\dagger$ Division of Biometry, Central Agricul- \\ tural Research Institute, Gannoruwa, Sri Lanka
}

\begin{abstract}
Accepted for publication 14 August 1986
Summary The occurrence of the post-lepromin scar was investigated in two general population groups, in two geographically different areas, in whom reactivity to lepromin A and SPA of Mycobacterium leprae were also studied, earlier. The incidence of the scar was more or less similar to that reported in a patient group in Burma. The incidence of scar was not related to age, sex, race or geographic area (even though examination for the scar was carried out in 3 months at one area and 7 months at the other). The occurrence of the scar increased with BCG vaccination, and was directly related to Mitsuda, Fernandez and SPA reactivity - being most correlated to Mitsuda reactivity and least to SPA reactivity.
\end{abstract}

\section{Introduction}

It has been known for a long time that the lepromin test may lead to the formation of a scar, or an area of atrophy. However, no systematic investigation of the latter was made, until $1977 .^{1}$ The latter concluded, from an evaluation of the scar in a series of leprosy patients, that 'the post-lepromin scar may be considered as an indicator for a stabilized immune situation. . '. The above study was carried out using lepromin of human origin with a bacillary content of 160 million bacilli per $\mathrm{ml}$. The same workers suggested that further studies be carried out using weaker lepromins and nonleprosy affected groups. In this paper we report a study of the scar following lepromin testing in two population groups in geographically different areas of Sri Lanka.

\section{Materials and methods}

The test populations, the method of the tests, etc., were as described earlier. ${ }^{2.3}$ One study ${ }^{1}$ considered the post-lepromin scar to be 'best read' at least 3-4 months after the late lepromin reaction, and is perfectly visible after many years. The populations studied were examined for the presence and size 
1Table 1. Occurrence of the post-lepromin test scar

\begin{tabular}{|c|c|c|c|c|c|c|c|c|c|c|c|c|c|c|c|c|c|c|c|}
\hline \multirow[b]{3}{*}{ Area } & \multicolumn{9}{|c|}{ BCG not vaccinated } & \multicolumn{9}{|c|}{ BCG vaccinated } & \multirow{3}{*}{$\begin{array}{l}\text { Total of } \\
\text { both BCG } \\
\text { vaccinated } \\
\text { and non } \\
\text { vaccinated }\end{array}$} \\
\hline & \multicolumn{2}{|c|}{$\mathrm{S}$} & \multicolumn{2}{|c|}{$\mathrm{T}$} & \multicolumn{4}{|c|}{ Total } & \multirow{2}{*}{$\begin{array}{c}\text { Total } \\
\text { of all } \\
\text { individuals }\end{array}$} & \multicolumn{2}{|c|}{ S } & \multicolumn{2}{|c|}{$\mathrm{T}$} & \multicolumn{4}{|c|}{ Total } & \multirow{2}{*}{$\begin{array}{c}\text { Total } \\
\text { of all } \\
\text { individuals }\end{array}$} & \\
\hline & $\mathbf{M}$ & $\mathrm{F}$ & $\mathbf{M}$ & $\mathrm{F}$ & $\mathrm{S}$ & $\mathrm{T}$ & $\mathbf{M}$ & $\mathrm{F}$ & & $\mathbf{M}$ & $\mathrm{F}$ & $\mathbf{M}$ & $\mathrm{F}$ & s & $\mathrm{T}$ & $\mathbf{M}$ & $\mathrm{F}$ & & \\
\hline \multicolumn{20}{|c|}{ Mahagastota } \\
\hline Scart & - & 1 & 5 & 10 & 1 & 15 & 5 & 11 & $\begin{array}{c}16 \\
(36)\end{array}$ & 1 & 1 & 5 & 11 & 2 & 16 & 6 & 12 & $\begin{array}{c}18 \\
(60)\end{array}$ & $\begin{array}{c}34 \\
(46)\end{array}$ \\
\hline Scar - & - & 2 & 9 & 17 & 2 & 26 & 9 & 19 & $\begin{array}{c}28 \\
(64)\end{array}$ & - & 1 & 2 & 9 & 1 & 11 & 2 & 10 & $\begin{array}{c}12 \\
(40)\end{array}$ & $\begin{array}{c}40 \\
(54)\end{array}$ \\
\hline \multicolumn{20}{|l|}{ Galagedera } \\
\hline Scar + & 7 & 19 & 5 & 6 & 26 & 11 & 12 & 25 & $\begin{array}{c}37 \\
(42)\end{array}$ & 9 & 20 & 9 & 14 & 29 & 23 & 18 & 34 & $\begin{array}{c}52 \\
(70)\end{array}$ & $\begin{array}{c}89 \\
(55)\end{array}$ \\
\hline Scar- & 12 & 23 & 3 & 13 & 35 & 16 & 15 & 36 & $\begin{array}{c}51 \\
(58)\end{array}$ & 2 & 10 & 2 & 8 & 12 & 10 & 4 & 18 & $\begin{array}{c}22 \\
(30)\end{array}$ & $\begin{array}{c}73 \\
(45)\end{array}$ \\
\hline
\end{tabular}

M, male; F, female; S, Sinhala; T, Tamil (percentages within parenthesis). 
of the scar at 7 months (at Mahagastota) and at 3 months (at Galagedera). Thus a total of 74 individuals at Mahagastota, and 162 at Galagedera, were examined.

\section{Results}

In Table 1 the occurrence of individuals with post-lepromin scars is presented. In both areas, the BCG vaccinated showed a greater incidence of the occurrence of scars than those not so vaccinated. There seemed also to be a slight increase in the occurrence of scars at Galagedera (at lower altitude) than at Mahagastota (at higher altitude), but whether this is due to geographic or other variations in the test population, or due to differences in time of examination for scar, are uncertain. However, statistical analysis showed that these differences are not significant.

The incidence of scars with different types of reactivity to antigens of $M$. leprae (namely, Mitsuda and Fernandez reactivity and that to Soluble Protein Antigen (SPA) of M. leprae) is presented in Tables 2, 3 and 4 respectively.

Table 5 gives a comparative analysis of the percentage incidence of scars in relation to the 3 types of reactivity to $M$. leprae antigens. Linear regression analysis revealed that the occurrence of the scar was highly correlated (at $1 \%$ level) with all 3 types of reactivity, the highest degree of relationship being with Mitsuda reactivity and lowest with SPA reactivity. Similarly, statistical analysis was carried out to evaluate the possible variability of the occurrence of the scar with age, sex and race. These variables were not found to effect its occurrence. Another variable, whose effect was obvious is that of BCG vaccination status. The occurrence of the scar is significantly higher in those who have been vaccinated in contrast to those not so vaccinated.

On examination of Mitsuda reactivity, it was found that in a few individuals, Mitsuda reactions had a different quality from what is described ${ }^{2}$-instead of being of the well defined, circumscribed

Table 2. Occurrence of the post-lepromin test scar in relation to Mitsuda reaction size

\begin{tabular}{|c|c|c|c|c|c|c|}
\hline \multirow[b]{2}{*}{$\begin{array}{l}\text { Mitsuda reaction } \\
\text { size }(\mathrm{mm})\end{array}$} & \multirow[b]{2}{*}{$\begin{array}{l}\text { Population } \\
\text { group }\end{array}$} & \multirow[b]{2}{*}{$\begin{array}{l}\text { BCG non- } \\
\text { vaccinated }\end{array}$} & \multirow[b]{2}{*}{$\begin{array}{c}\text { BCG } \\
\text { vaccinated }\end{array}$} & \multicolumn{2}{|c|}{ Total of both areas } & \multirow[b]{2}{*}{ Grand total } \\
\hline & & & & $\begin{array}{l}\text { BCG non- } \\
\text { vaccinated }\end{array}$ & $\begin{array}{c}\text { BCG } \\
\text { vaccinated }\end{array}$ & \\
\hline $0-2$ & Mahagastota & $\begin{array}{r}2(14) \\
12(86)\end{array}$ & $\begin{array}{ll}2 & (40) \\
3 & (60)\end{array}$ & $\begin{array}{r}6(15) \\
35(85)\end{array}$ & $\begin{array}{ll}3 & (25) \\
9 & (75)\end{array}$ & $\begin{array}{r}9(17) \\
44(83)\end{array}$ \\
\hline & Galagedera & $\begin{aligned} 4 & (15) \\
23 & (85)\end{aligned}$ & $\begin{array}{l}1(14) \\
6(86)\end{array}$ & & & \\
\hline \multirow[t]{2}{*}{$3-5$} & Mahagastota & $\begin{array}{ll}4 & (36) \\
7 & (64)\end{array}$ & $\begin{array}{l}4(57) \\
3(43)\end{array}$ & $\begin{array}{l}10(33) \\
20(67)\end{array}$ & $\begin{array}{l}12(55) \\
10(45)\end{array}$ & $\begin{array}{ll}22 & (42) \\
30 & (58)\end{array}$ \\
\hline & Galagedera & $\begin{array}{r}6(32) \\
13(68)\end{array}$ & $\begin{array}{l}8(53) \\
7(47)\end{array}$ & & & \\
\hline $6-9$ & Mahagastota & $\begin{array}{l}4(50) \\
4(50)\end{array}$ & $\begin{array}{l}7(70) \\
3(30)\end{array}$ & $\begin{array}{l}22(69) \\
10(31)\end{array}$ & $\begin{array}{ll}34 & (76) \\
11 & (24)\end{array}$ & $\begin{array}{ll}56 & (73) \\
21 & (27)\end{array}$ \\
\hline & Galagedera & $\begin{array}{r}18(75) \\
6(25)\end{array}$ & $\begin{array}{r}27 \text { (77) } \\
8(23)\end{array}$ & & & \\
\hline \multirow[t]{4}{*}{$\geq 10$} & Mahagastota & 3 & 4 & $10(100)$ & $19(100)$ & $29(100)$ \\
\hline & & - & - & - & - & - \\
\hline & Galagedera & 7 & 15 & & & \\
\hline & & - & - & & & \\
\hline
\end{tabular}

With scar-upper row; without scar-lower row; percentages within parenthesis. 
Table 3. Occurrence of the post-lepromin test scar in relation to Fernandez. reaction size

\begin{tabular}{|c|c|c|c|c|c|c|}
\hline \multirow{2}{*}{$\begin{array}{l}\text { Fernandez } \\
\text { reaction size } \\
\quad(\mathrm{mm})\end{array}$} & \multirow[b]{2}{*}{$\begin{array}{l}\text { Population } \\
\text { group }\end{array}$} & \multirow[b]{2}{*}{$\begin{array}{l}\text { BCG non- } \\
\text { vaccinated }\end{array}$} & \multirow[b]{2}{*}{$\begin{array}{c}\text { BCG } \\
\text { vaccinated }\end{array}$} & \multicolumn{2}{|c|}{ Total of both areas } & \multirow[b]{2}{*}{ Grand total } \\
\hline & & & & $\begin{array}{l}\text { BCG non- } \\
\text { vaccinated }\end{array}$ & $\begin{array}{c}\text { BCG } \\
\text { vaccinated }\end{array}$ & \\
\hline \multirow[t]{2}{*}{$0-2$} & Mahagastota & $5(20)$ & $7(44)$ & $15(28)$ & $15(44)$ & $30(35)$ \\
\hline & Galagedera & $\begin{array}{ll}10 & (36) \\
18 & (64)\end{array}$ & $\begin{aligned} 8 & (44) \\
10 & (56)\end{aligned}$ & & & \\
\hline \multirow[t]{2}{*}{$3-9$} & Mahagastota & $\begin{array}{ll}5 & (39) \\
8 & (61)\end{array}$ & $\begin{array}{ll}6 & (67) \\
3 & (33)\end{array}$ & $\begin{array}{ll}22 & (38) \\
36 & (62)\end{array}$ & $\begin{array}{ll}29 & (67) \\
14 & (33)\end{array}$ & $\begin{array}{ll}51 & (50.5) \\
50 & (49.5)\end{array}$ \\
\hline & Galagedera & $\begin{array}{l}17(38) \\
28(62)\end{array}$ & $\begin{array}{l}23(68) \\
11(32)\end{array}$ & & & \\
\hline 10 & Mahagastota & $\begin{array}{ll}4 & (80) \\
1 & (20)\end{array}$ & $5(100)$ & $\begin{aligned} 12 & (67) \\
6 & (33)\end{aligned}$ & $27(100)$ & $\begin{array}{r}39(87) \\
6(13)\end{array}$ \\
\hline$\geq$ & Galagedera & $\begin{array}{ll}8 & (62) \\
5 & (38)\end{array}$ & $22(100)$ & & & \\
\hline
\end{tabular}

With scar-upper row; without scar-lower row; percentages within parenthesis.

Table 4. Occurrence of the post-lepromin test scar in relation to SPA reaction size

\begin{tabular}{|c|c|c|c|c|c|c|}
\hline \multirow[b]{2}{*}{$\begin{array}{l}\text { SPA reaction } \\
\text { size }(\mathrm{mm})\end{array}$} & \multirow[b]{2}{*}{$\begin{array}{l}\text { Population } \\
\text { group }\end{array}$} & \multirow[b]{2}{*}{$\begin{array}{l}\text { BCG non- } \\
\text { vaccinated }\end{array}$} & \multirow[b]{2}{*}{$\begin{array}{c}\text { BCG } \\
\text { vaccinated }\end{array}$} & \multicolumn{2}{|c|}{ Total of both areas } & \multirow[b]{2}{*}{ Grand total } \\
\hline & & & & $\begin{array}{l}\text { BCG non- } \\
\text { vaccinated }\end{array}$ & $\begin{array}{c}\text { BCG } \\
\text { vaccinated }\end{array}$ & \\
\hline \multirow[t]{3}{*}{$0-2$} & Mahagastota & $7(26)$ & $2(25)$ & $14(24)$ & $4(21)$ & $18(23)$ \\
\hline & & $20(74)$ & $6(75)$ & $44(76)$ & $15(79)$ & $59(77)$ \\
\hline & Galagedera & $\begin{array}{r}7(23) \\
24(77)\end{array}$ & $\begin{array}{l}2(18) \\
9(82)\end{array}$ & & & \\
\hline \multirow[t]{3}{*}{ *3-9 } & Mahagastota & $3(100)$ & $3(60)$ & $14(48)$ & $19(73)$ & $33(60)$ \\
\hline & & - & $2(40)$ & $15(52)$ & $7(27)$ & $22(40)$ \\
\hline & Galagedera & $\begin{array}{l}11(42) \\
15(58)\end{array}$ & $\begin{array}{r}16(76) \\
5(24)\end{array}$ & & & \\
\hline \multirow[t]{3}{*}{$\geq 10$} & Mahagastota & $9(64)$ & $14(88)$ & $26(62)$ & $44(85)$ & $70(75)$ \\
\hline & & $5(36)$ & $2(12)$ & $16(38)$ & $8(15)$ & $24(25)$ \\
\hline & Galagedera & $\begin{array}{l}17(61) \\
11(39)\end{array}$ & $\begin{aligned} 30 & (83) \\
6 & (17)\end{aligned}$ & & & \\
\hline
\end{tabular}

With scar-upper row; without scar-lower row; percentages within parenthesis.

* Note: Though $5 \mathrm{~mm}$ was considered a 'positive' reaction for SPA reactivity, ${ }^{3}$ it was thought that there would be no serious error in considering $3 \mathrm{~mm}$ as the demarcation for 'positive'. Therefore in order to have similar class intervals for comparative purposes (Table 5) $3-9 \mathrm{~mm}$ is included as the second class interval in this Table. 
Table 5. Occurrence of the post-lepromin test scar with different reaction sizes of different types of reactivity to antigens of $M$. leprae (percentages of individuals showing scars)

\begin{tabular}{lccccccc}
\hline & \multicolumn{2}{c}{ BCG not vaccinated } & & \multicolumn{3}{c}{ BCG vaccinated } \\
\cline { 2 - 3 } \cline { 6 - 8 } $\begin{array}{l}\text { Reaction size } \\
(\mathrm{mm})\end{array}$ & Mitsuda & Fernandez & SPA & & Mitsuda & Fernandez & SPA \\
\hline $0-2$ & 15 & 28 & 24 & & 25 & 44 & 21 \\
$3-9$ & 52 & 38 & 48 & & 69 & 67 & 73 \\
$\geq 10$ & 100 & 67 & 62 & & 100 & 100 & 85 \\
\hline
\end{tabular}

nodule type-yielding a soft and some times plaque-like reaction. The post-lepromin scar was seen in 2 (of 10 such reactions, all of $3 \mathrm{~mm}$ or more) at Galagedera, and 3 (of 11 ) at Mahagastota- $24 \%$ of the total, whereas $67 \%$ of the total with typical reactions showed scars.

\section{Discussion}

The results reported here are of a lepromin test with a lepromin of a lower bacillary content $\left(4 \times 10^{7}\right)$ $\mathrm{ml}$ ), and of armadillo origin; carried out on a general population group without any evidence of leprous disease. Hence the results of this study may not be directly comparable with those reported in another'. It is noteworthy that broadly, the findings of this study appear to be similar to those of the latter workers, with leprosy patients. For example, in the $0-2 \mathrm{~mm}$ and 3-5 mm Mitsuda reaction sizes, $17 \%$ and $32 \%$ respectively of patients in the Walter et al. study showed scars (with first or subsequent testing), while in this investigation, $17 \%$ and $42 \%$ respectively of members of the general population also showed scars (with only 1 test).

The other situation in which scars are presently examined for after an inoculation, is in the assessment of 'coverage' of BCG vaccination programmes-by looking for the presence of scars in those given BCG vaccination. ${ }^{4}$ Here it is said that with a potent vaccine, a scar is seen in almost $100 \%$ of those so vaccinated, ${ }^{4}$ though not invariably so. ${ }^{5}$ In Sri Lanka, however, a scar was not found after confirmed BCG vaccination in 3.4\% of 750 children between the ages of 3 months and 11 years (at the time of examination), given BCG vaccination at birth. ${ }^{6}$ In comparison, the occurrence of scars following lepromin testing is of much lower incidence. If as considered earlier, the post-lepromin scar is an indicator of immunological status, ${ }^{1}$ then, as could be expected, lepromin may be considered to be a much weaker vaccine than BCG.

\section{Acknowledgments}

This investigation was supported in part by a grant from the Leprosy Section, World Health Organization, Geneva.

We wish to thank Mr D W Dissanayake, Medical Assistant, Mahagastota State Plantation, Nuwara Eliya, and Ms M G Kusumalatha, Medical Assistant, Trafford Hill State Plantation, Galagedera, for assistance in carrying out this study; and Ms T M Gamage and Ms M Wijekoon, of the Department of Microbiology, Faculty of Medicine, University of Peradeniya, for assistance in data analysis. 


\section{References}

1 Walter J, Tamongdong CT, Gallego Garbajosa P, et al. Note on some observations about the post-lepromin scar. Lepr Rev, 1977; 48: 169-74.

2 Pinto MRM, Eriyagama NB, Pemajayantha V. Studies of reactivity of some Sri Lankan population groups to antigens of Mycobacterium leprae: I. Reactivity to Lepromin A. Lepr Rev 1987; 58: 105-118.

${ }^{3}$ Pinto MRM, Eriyagama NB, Pemajayantha V. Studies of reactivity of some Sri Lankan population groups to antigens of Mycobacterium leprae: II. Reactivity to a Soluble Protein Anigen of M. leprae. 1987; 58: 219-26. preparation.

4 Ten Dam HG, Toman K, Hitze KL, Guld J. Present knowledge of immunisation against tuberculosis. Bull World Health Organ, 1976; 54: 255-68.

5 Ten Dam HG, Hitze KL. Determining the prevalence of tuberculosis infection in populations with nonspecific tuberculin sensitivity. Bull World Health Organ, 1980; 58: 3: 475-83.

${ }^{6}$ Karalliedde S, Katugaha L. Response to tuberculin testing after BCG at birth. Paper presented at Joint Scientific Sessions of the Kandy Society of Medicine and Sri Jayawardenepura Hospital, Kotte. Abstracts of Clinical Sessions, Sri Jayawardenepura General Hospital, Kotte. 1985; 14.

\section{NEWS AND NOTES}

\section{Slide/script and audiotape sets on leprosy (English)}

American Leprosy Missions now has available two slide-script and tape sets produced by Roy Pfaltzgraff. Details are as follows:

Leprosy in general practice-this set of 80 slides briefly covers the essentials of the diagnosis and management of leprosy for a medical practitioner who has had little or no previous experience with leprosy. It gives guidelines on the basic features of the disease, the treatment and the main complications that may arise during the active course of the disease, and what to do in case complications arise. (length, 32 minutes).

'Differential diagnosis of leprosy' - consists of 80 slides chiefly of African dermatological conditions that may be confused with leprosy. The emphasis is on making a definite diagnosis by clinical methods in a 'field' situation. It provides a good overview of tropical dermatology. (length, 22 minutes).

These sets are available at the subsidized price of US\$10.00 per set, including a tape and printed script. Apply to: American Leprosy Missions, One Broadway, Elmwood Park, New Jersey 07407, USA.

\section{Questions and Answers on the Implementation of Multiple Drug Therapy (MDT) in Leprosy. Portuguese translation}

This booklet of 35 pages is available, in English and Portuguese, from the Health Unit, OXFAM 274 Banbury Road, Oxford OX2 7DZ, England. It includes a number of questions, and some of the answers, relating to problems which may arise in the practical implementation of multiple drug therapy, using the regimens recommended by WHO. Attention has however been drawn, notably by readers in South America, to a number of defects in the Portuguese translation and these include the following: Certain words are inadequately chosen to describe the real meaning, for example: 'exame dos testes microscopicos do corte da pele,' should be 'baciloscopia de espregaço de corte de pele'. For 'pauci-bacilar' substitute 'paucibacilifero'; for 'multi-bacilar' substitute 'multibacilifero'; for 'reincidencia' substitute 'recidiva o recaida'; for 'sitio' substitute 'local o region'; for 'beneficial' substitute 'benéfico'. 'Leprosos' is a derogatory expression that should not be used, the correct term is 'paciente de lepra'.

Further comments on the quality of translation are being collected and a correction slip will be included in copies of the present edition, pending the possibility of a full revision. 